\title{
河川レーザ測量のための 水面下河床高の力学的内挿補間法 HYDRODYNAMIC INTERPOLATION METHOD OF SUBMERGED RIVER BED TOPOGRAPHY FOR LASER SCANNING SURVEY
}

\author{
内田龍彦 1 河原能久 $2 \cdot$ 吉田 晋 3 ・森山 学 4 \\ Tatsuhiko UCHIDA, Yoshihisa KAWAHARA, Susumu YOSHIDA and Manabu MORIYAMA \\ 1正会員 博 (工) 広島大学助教 大学院工学研究科（干739-8527 東広島市鏡山1-4-1） \\ 2 フェロー会員 工博 広島大学教授 大学院工学研究科 (同上) \\ 3 学生会員 広島大学工学部第四類（同上） \\ 4 非会員 復建調查設計株式会社 空間情報システム部（テ732-0052 広島県広島市東区光町二丁目10-11）
}

\begin{abstract}
Recently 3D laser scanner systems have been widely and effectively used to measure the physical environment of river. However, it is still very difficult to obtain submerged river bed topography. To overcome this problem, this paper proposes a new and practical method to interpolate the submerged bed elevation to compensate for the weak points of laser systems. First, we obtain the detailed bed data in an experimental channel by a laser scanner system. The performance of a geometric interpolation method using bed elevation and its gradient at water edges is discussed. Then we show the significance of water surface profile in estimating river bed profile through the comparisons between the interpolated and the measured data. And we formulate a new hydrodynamic interpolation method of river bed topography under water surface using water surface profile. The hydrodynamically interpolated submerged bed river shape is found to show good agreement with the measured data.
\end{abstract}

Key Words: laser scanner, ground data, submerged river bed topography, water surface, geometric interpolation method, hydrodynamic interpolation method, 2D numerical analysis

\section{1. 序論}

現在，コンピュータ技術の進展により，洪水流の二次 元不定流解析は実務レベルでも可能となっている. しか し, 解析に必要なデータが質・量ともに不十分であるこ とが数值解析上の大きな障害となっている. このため, 場所的，時間的に変化している河道特性のデータを整備 することが急務である．航空レーザ測量 ${ }^{1), 2}$ は，三次元 座標を経済的かつ一定の品質で大量に取得できるという 技術的な特徴から, 河川の物理環境データを生成できる 可能性があり，近年注目されている．しかし，一方で航 空機の運用コストが高いこと，高度が高いために計測誤 差が小さくないことに加え, 植生が繁茂する状況での地 盤高の取得技術が確立されていないこと等の課題が残さ れている. 特に, 水面下の河床データについては, レー ザの安全規格の面からレーザ光の強度が制限されること と, 水表面での反射及び屈折により, データ取得が困難 であることが指摘されている゙ ${ }^{3}$ ．この弱点を克服するた
め, 例えば傳田ら ${ }^{4)}$ はレーザスキャナの陸域の河床高 データと水深による航空写真のRGB值の変化を用いて, 水面下河床データの補間法を提案している. しかし, こ の方法ではRGB值と水深の相関関係を求めるために多数 の点での水深計測が必要なことと, RGB值は水面や河床 の条件等によっても変化するため, 水面下河床高データ の算出の際には特別なフィルタリング技術が必要である. 著者ら ${ }^{5)}$ ，低空を飛行できる小型有人へリコプタに 搭載した，高精度の3Dレーザスキャナ（LISA）を用い て太田川（11K〜12K）においてレーザ測量を行った. その結果, 高精度かつ高密度のレーザ測量では, 水域で データが取得できないことを生かして, 水際の河床高 データから水際の河川水位を高精度で推定できること, 河床高データの局所的な分散から河床材料の代表粒径を 推定できることを示した. 洪水流に対する水面形のもつ 重要性については福岡(6)が取り纏めているが，ここでは 河川レーザ測量を行う低水時を対象とする. 定常状態で 流量が与えられる場合, 水面形に大きな影響を与える因 子は, 河床形状及び粗度係数である. 水位が低い低水状 


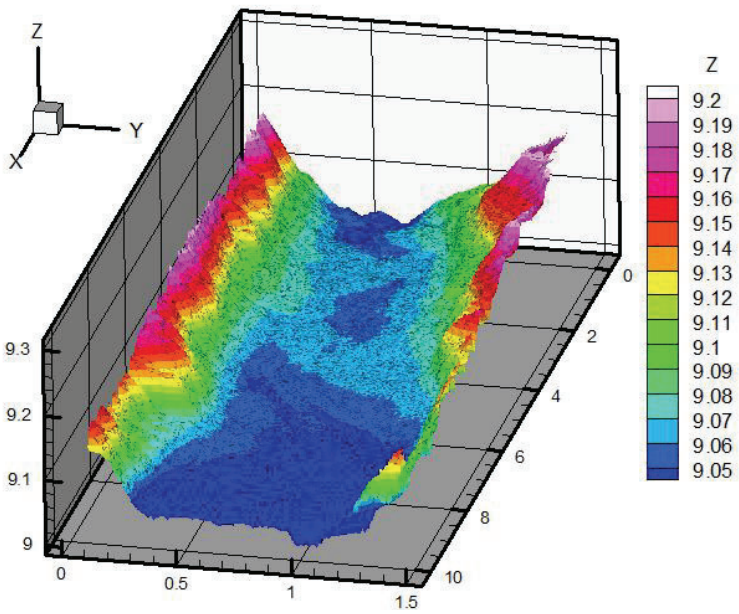

(a) 河床形状

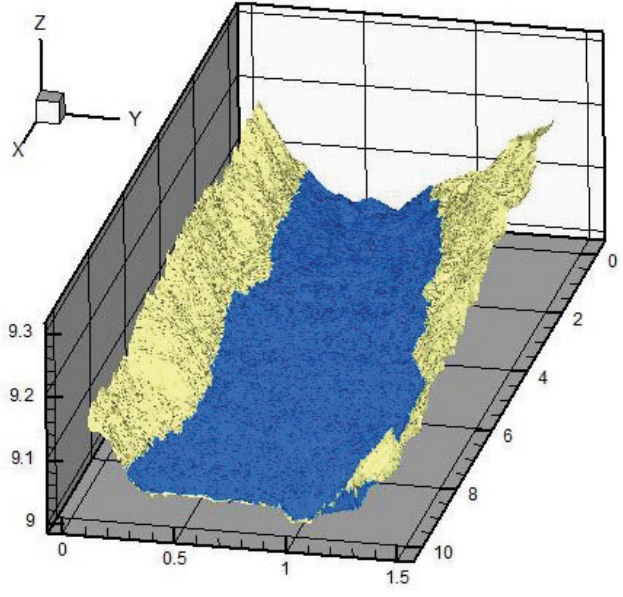

（b）通水時の水域と陸域（中央の青い部分が水域）

図-1 レ一ザ計測された河床形状と水域と陸域の色分け

態においては, 水域に植生が少ないため, 粗度係数の場 所的な変化は大きくはないと考えられる. また, 水面下 の河床データの誤差は水位が高い洪水流解析に影響を与 えない程度に小さければよいと考えられる.このため, レーザスキャナから取得される水際の水位を用いて，水 面下の河床形状を推定することは工学上必要な精度で可 能と考えられる.

本研究では移動床実験によって生成された河床形状に 一定流量を通水した際の水面形データと陸域の河床形状 データから二次元数值解析を介した水面下データの力学 的な補間法を検討する.

\section{2. 水理実験による検証データの取得と水面下河 床形状の表現方法の検討}

\section{（1）水理実験による検証データの取得}

本研究では，河川レーザ測量の際の水面下データの取 得を目的とするが，検証を行うために河川の詳細な三次 元データを取得することは困難である，そこで，本研究 では移動床水理実験によって生成された河床形状を用い る. 河床形状は, 幅1.5 mの直線水路において, 縦断方 向に $10 \mathrm{~m}$ の区間に一様粒径 $d_{0}=0.8 \mathrm{~mm}$ 砂を水路中央部 がやや低くなるように敷詰め，側岸際の河床が非水没の 状態で通水を行った後，河床を市販のセメダインを用い て固化して作成している. 生成した河床形状は固定式の レーザプロファイラ（ライカジオシステムズ社製）を用 いて測定する．計測点密度はレーザプロファイラから最 も離れた計測地点で1点 $/ \mathrm{cm}^{2}$ 程度となるように設定して いる．図-1 (a) は計測データから作成した $1 \mathrm{~cm}$ 格子の メッシュデータである. 流量 $Q=3.5 \times 10^{-3} \mathrm{~m}^{3} / \mathrm{s}$ を通水し た際にも同様に計測し，陸域と水域データを区分し（図 $-1(b))$ ，水際データから水位データを取得する ${ }^{5)}$. 通水 時の水面位置と最深河床高の縦断形状については図-7に 示しており，水路中央部の河床及び水面勾配は約 $1 / 200$

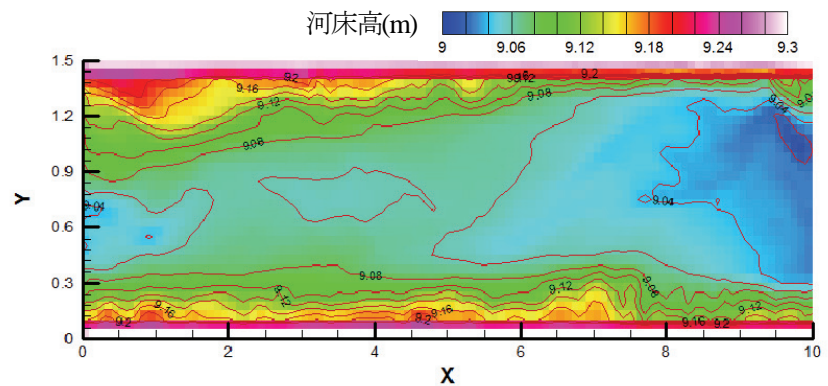

図-2 河床高の真值として用いるメッシュデータ $(d x=0.10 \mathrm{~m}, d y=0.050 \mathrm{~m})$

である，ただし，縦断水面形の計測值は，実験水路のス ケールにおいては水際点の水位の精度が十分でなく, 縦 断方向に逆勾配が生ずる場合があったため, 縦断水面形 の計測值には水位が逆勾配とならないように極值を除去 するフィルターを掛けている．以下，本論文では， 1 $\mathrm{cm}$ 格子データを空間平均することによって得られる, $d x=0.10 \mathrm{~m}, d y=0.050 \mathrm{~m}$ の河床高のメッシュデータ（図2）を河床高の真值として用いる.

\section{（2）水面下河床形状の簡便な表現方法の検討}

本研究では，次章で述べるように水位データから水面 下の河床高の最適值を求める問題として定式化するが, 水域の全メッシュの河床高に自由度を持たせ，その最適 值を求めることは困難である，そこで，周囲の河床高の 幾何学的情報のみから簡便に水面下の河床高を表現する 方法を検討寸る，本論文ではレーザ計測により，水域以 外の河床高のデータが高精度かつ高密度に得られている ことと，補間断面の上下流端は横断測量により河床形状 が得られていることを前提にする.

低水時の任意の形状をもつ水域の地盤高を内挿する最 も簡単な方法の一つに，陸域の河床高と横断測量による 河床高データを境界值として, 式(1)のラプラス方程式 を解くことが考えられる.

$$
\nabla^{2} z=0
$$




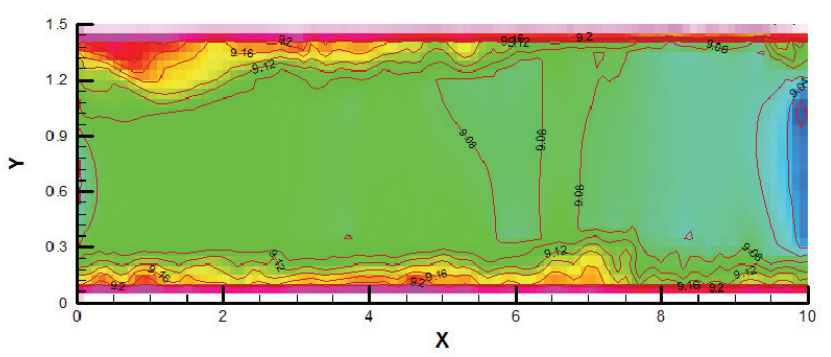

（a）河床高のラプラス方程式を用いる場合

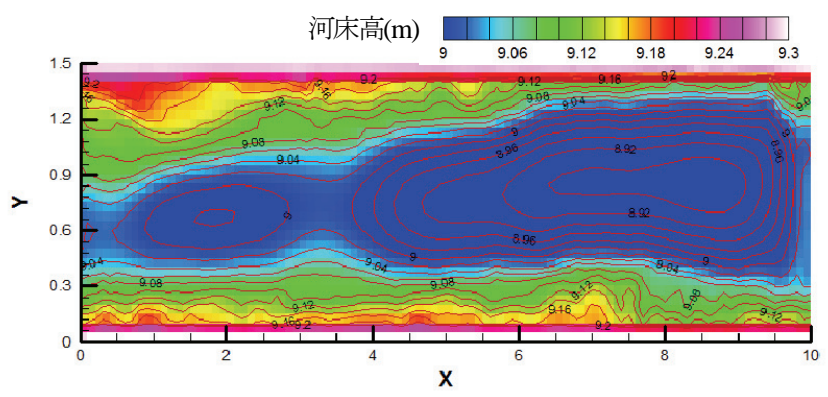

（b）河床勾配のラプラス方程式を用いる場合

図-3 ラプラス方程式によって補間された河床形状の特徵

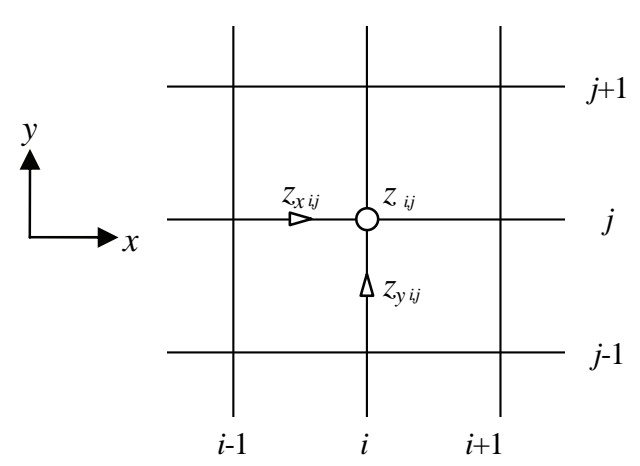

図-4 河床高と河床勾配の変数配置

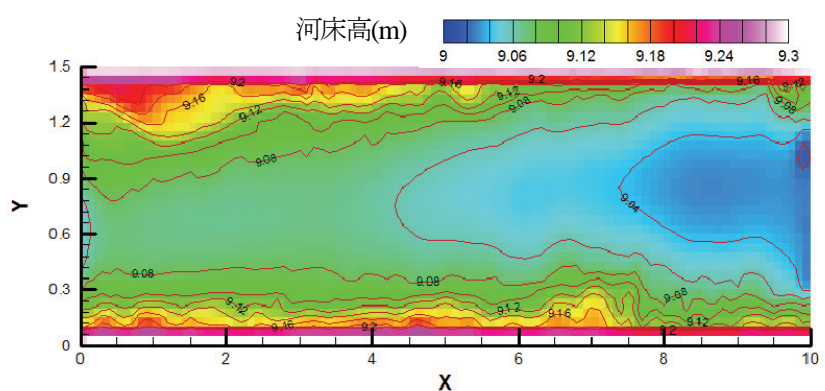

(a) 河床高の補間值

図-6 水深補正係数 $\alpha$ の最適值 $(\alpha=0.2)$

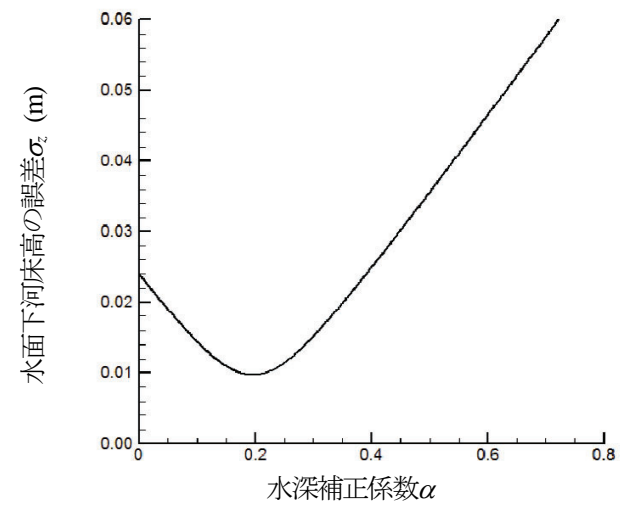

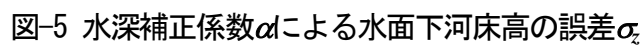

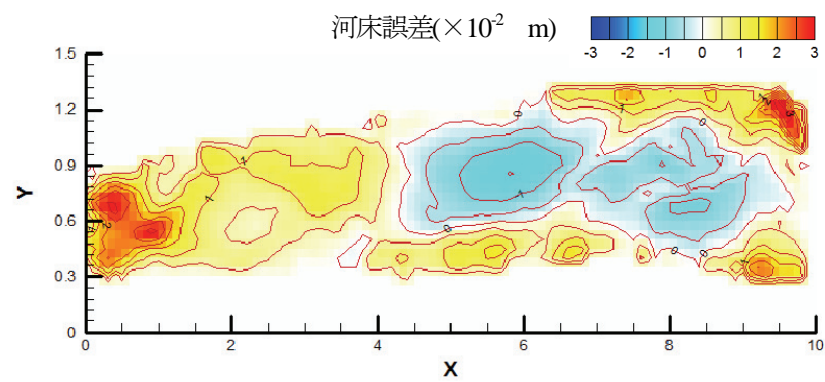

(b) 河床高の補間値と真値の差

\section{を用いて補正された河床形状と誤差}

(2)，(3)により得られる水域の勾配ベクトルと陸域の河 床高を用いて式(4)を解くことによって, 水域の河床高 を補間する。

$$
\begin{gathered}
z_{i, j}=\frac{1}{4}\left(z_{i-1, j}+z_{x_{i, j}} \cdot d x\right)+\frac{1}{4}\left(z_{i+1, j}-z_{x_{i+1, j}} \cdot d x\right) \\
+\frac{1}{4}\left(z_{i, j-1}+z_{y i, j} \cdot d y\right)+\frac{1}{4}\left(z_{i, j+1}-z_{y i, j+1} \cdot d y\right)
\end{gathered}
$$

図-3 (b) は式(2)〜 (4) を用いて補間された河床形状であ る. 水際では水域方向に向かって河床高が低下寸るため, 水域中央ほど低下寸る河床が計算される.

任意の河床高を表現するため，式(1)より計算される 水面下河床高 $\mathrm{z}_{0}$, 式 (2) (4) を用いる場合の $\mathrm{z}_{1}$ と, 水深 の補正係数 $\alpha(>0)$ を用いて, 水面下河床高 $z_{w}$ を式(5) で定義する.

$$
z_{w}=z_{0}+\alpha\left(z_{1}-z_{0}\right)
$$

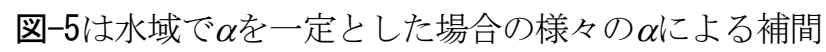




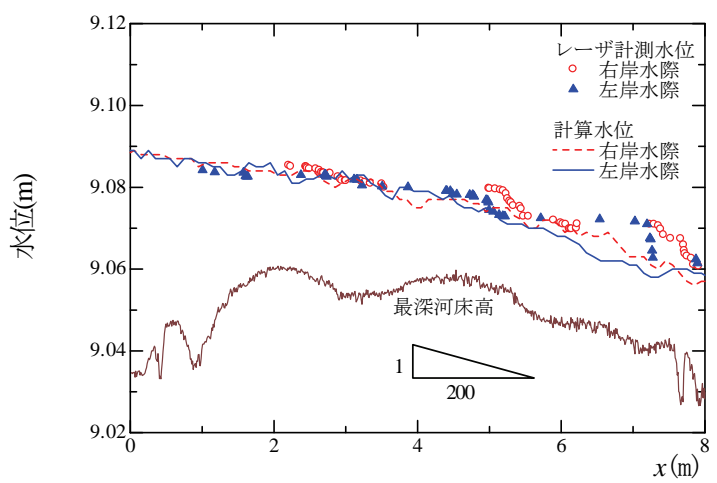

図-7 河床高の真值を与える場合の縱断水面形

值と真值の標準偏差 $\sigma_{z}$ である．また，図-6は補間値の䛊 差を最小とする $\alpha$ の最適值 $\alpha=0.2$ における河床高の補間 值と河床形状と真值との誤差である. 図-5より $\alpha$ に一定 值を与えているため, 誤差が場所ごとに異なり， $\sigma_{z}$ はゼ 口とはならない，水面下河床高を求めるためには $\alpha$ の分 布形状を求める必要があるが，一定の $\alpha$ 用いてもある 程度実験の河床形状を表現できていることが分かる.

\section{3. 水面形を用いた水面下河床高の力学的内挿補 間法}

\section{（1）流れの数值解析法と水位誤差と河床誤差の関係}

水面形を用いて水面下河床高を内挿補間するために, 流れの数值解析を行う. 流れの解析ではデカルト座標系 の二次元浅水流方程式を基礎方程式とし，複雑な河床形 状を適切に評価するために著者らの保存型のCIP解法》を 用いる．境界条件は上流端で実験流量，下流端で実験水 位を与える. 計算格子は $d x=0.10, d y=0.050(\mathrm{~m})$ としてい る. 粗度係数は, 本来末知であるが，前述のようにレー ザ計測によって河床の代表粒径は推定可能である ${ }^{5}$ 。 そ こで，問題を簡単にするため，河床形状の真値（計測 值）を用いて，計算結果が実験の水際線や水面形々一致 するように求め, $k_{s}=0.030(\mathrm{~m})$ を与えている. 図-7に真 值の河床高を与えた場合の計算結果を示寸。計算結果は 下流端付近で実測結果と多少のずれを示すものの，それ 以外では水際線の縦断水位を概ね再現していると言える。 水面下の河床高の力学的内挿補間法の検討に先立ち, 水面形の誤差と河床形状の誤差を比較し，水面形から水 面下河床高を推定できるかどうかを検討する. 図-8は, 水域で一定と仮定した水深補正係数 $\alpha$ を変えて水面形を 計算し, 水域全体での水位の誤差 $\sigma_{H}$ と水深補正係数 $\alpha$ の 関係を示したものである.ここで，水面形の真值は真值 河床高を用いた計算結果としている. 水位の誤差 $\sigma_{H}$ は河 床の誤差 $\sigma_{z}$ (図-5) の場合のように単純ではなく, $\alpha=0.2$ と $\alpha=0.4$ の二つの極值を持った左右非対称形と なっている. この非対称性は, 計算の境界条件として下 流端水位が与えられるためである. 即ち, 河床高の誤差 は，真值に比べて河床高が高い場合には水位に明確な差

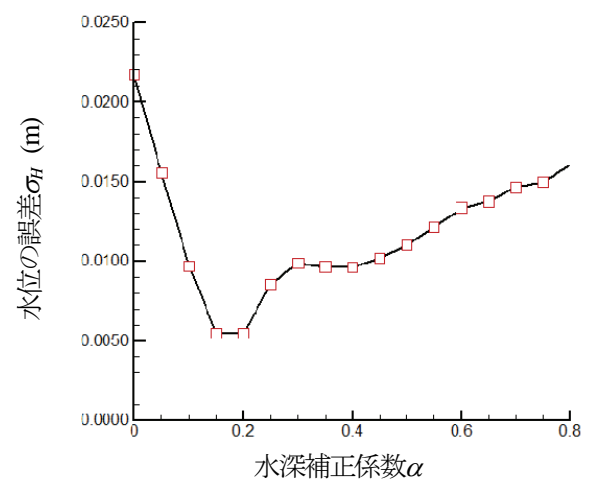

図-8 水深補正係数 $\alpha$ による水位の誤差 $\sigma_{z}$

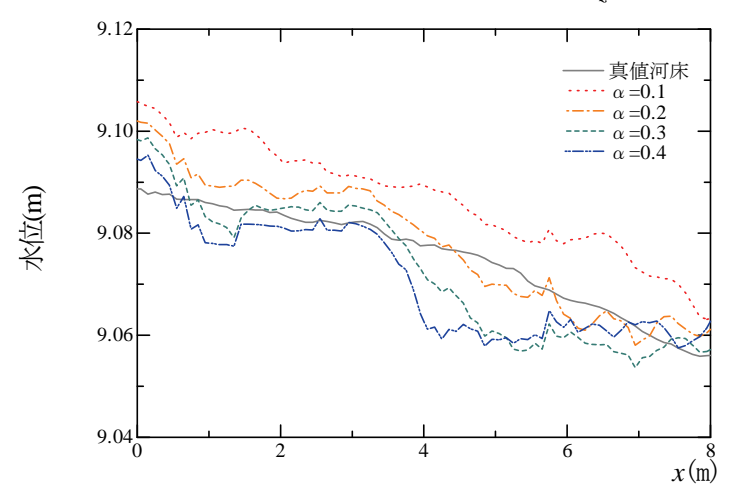

図-9 種々の水深補正係数 $\alpha$ による河床高と真值河床高を 与えた場合の横断平均縦断水面形の比較

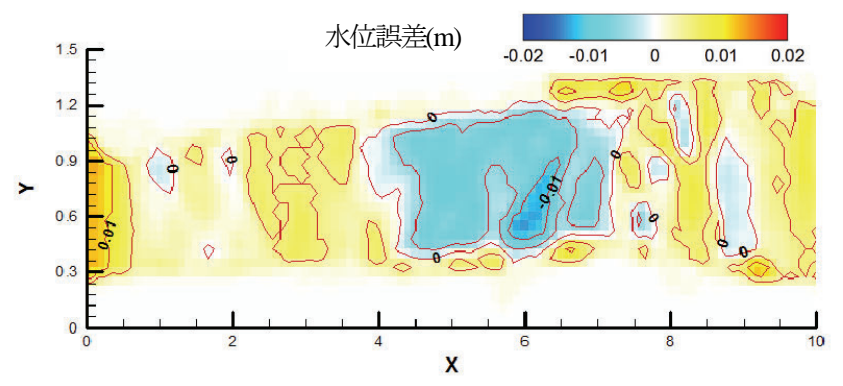

図-10 水位誤差を最小とする水深補正係数 $\alpha(=0.2)$ によ る水位誤差の分布

を生じさせるが，真值に比べて河床高が低い場合には水 位に表れにくいことを示している. しかし，全体として 下に凸の関数となっていることと，誤差が最小となるそ の極值の $\alpha$ は河床形状の場合とほぼ同值であることから， 水面形の誤差を最小とすることによって，水面下河床高 を推定することは可能と考えられる. 図-9に種々の水深 補正係数 $\alpha$ にる河床高と真值河床高を与えた場合の縦 断水面形の比較を示寸. 水深補正係数 $\alpha$ の最適值を用い た計算結果は，真值の河床高と全体的にはよく一致して いるが，図-6(b)に示したように場所ごとに水深補正係 数 は異なるため, 各点では水面形にも誤差が残ってい る. 図-10に水位誤差を最小とする水深補正係数 $\alpha(=0.2)$ による水位の誤差の分布を示す. 各点の河床高の差は底 面せん断力の影響を受けてその場所の水位の誤差を生じ させるため，図-6 (b) と図-10を比較すると全体的には似 ているが，河床形状と水面形の誤差分布形状は異なる. 


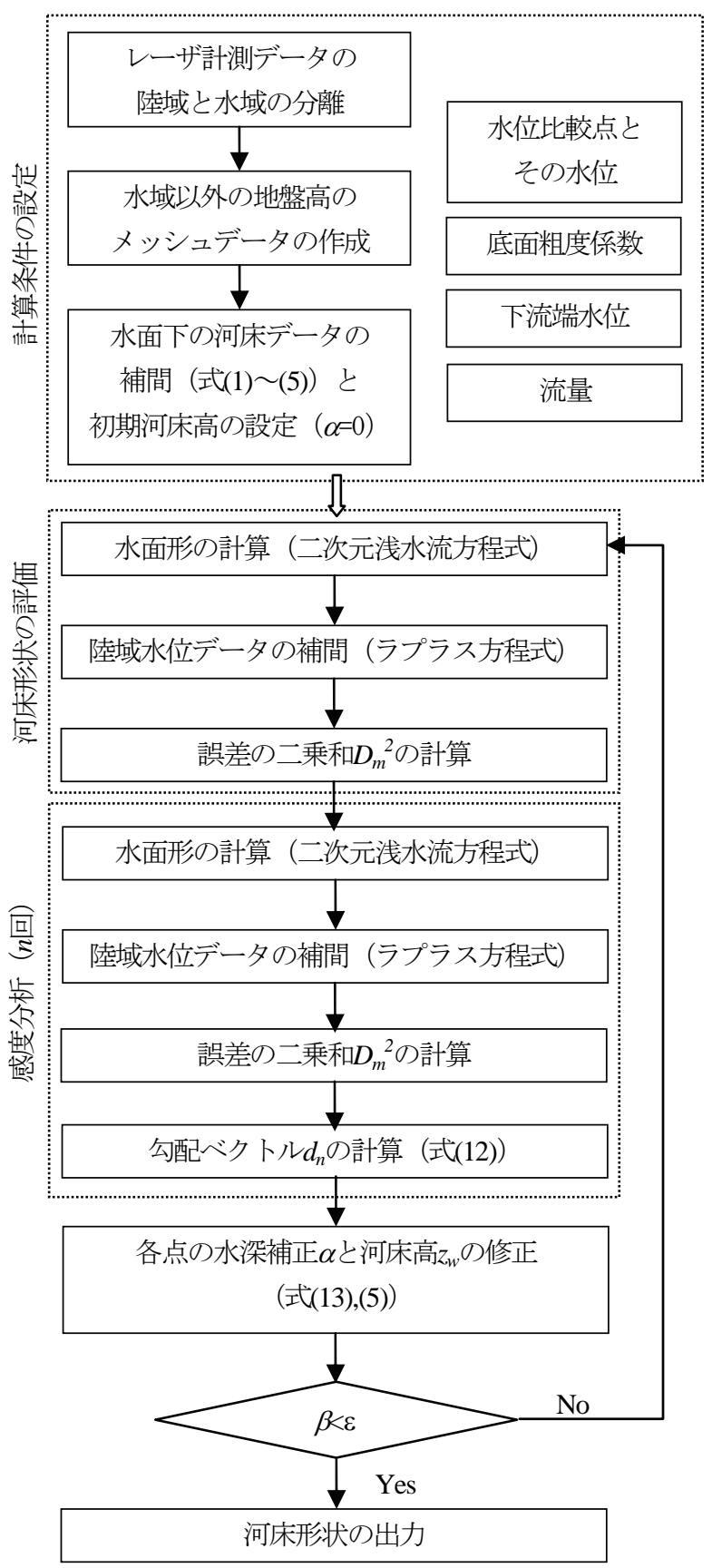

図-11 水面下の河床高の力学的内挿補間法の流れ

したがって，水面形の誤差分布から直接的に水深補正係 数 $\alpha$ の分布を推定することは困難である．また，実河川 では，水深補正係数 $\alpha$ の分布はより大きくなると考えら れる.このため，より適切に水面下の河床形状を補間す るには，水深補正係数 $\alpha$ の空間分布を考慮できる解析法 が不可欠と言える.

\section{（2）水面形を用いた水面下河床高の力学的内挿補間の定 式化}

本研究で取り扱う問題を，水面データが与えられてい る全ての点の誤差の二乗和 $D_{m}{ }^{2}$ を小さくするように，水 面下の任意の点 $n$ の河床高 $z_{n}$ を求めることとする．点 $n$ の 河床高 $z_{n}$ の微小変化 $\delta z_{n}$ に対寸る $D_{m}{ }^{2}$ の微小変化 $\left(\delta D_{m}{ }^{2}\right)_{n}$ を 表す勾配べクトル $d_{n}$ は式(6)で定義できる.

$$
d_{n}=\left(\delta D_{m}{ }^{2}\right)_{n} / \delta z_{n}
$$

今，誤差の二乗和 $D_{m}{ }^{2}$ を低減させる割合を $\beta$ とし，それに 必要な河床高の補正量 $\delta z_{n} か ゙ 十$ 分小さいとすると, 河床 高の修正量は式(7)で求まる. そこで，本問題を式(7)を 等式制約条件とする, 河床高の修正量 $\delta z_{n}{ }^{2}$ を最小化する, 非線形計画問題阳に置き換える.

$$
\begin{aligned}
& \text { 制約条件 } d_{n} \cdot \delta z_{n}=-\beta D_{m}{ }^{2} \\
& \text { 最小化 } \delta z_{n}{ }^{2} \rightarrow \text { min }
\end{aligned}
$$

ラグランジュの未定乗数法により, 各点の河床高の修正 ベクトル $\delta z_{n}$ と, 勾配ベクトル $d_{n}$ の関係が式(9)のように 求まる.

$$
2 \delta z_{n}+\lambda d_{n}=0
$$

式(9)を制約条件式(7)に代入すれば，未定乗数入は式(10) で求まる.

$$
\lambda=2 \beta D_{m}{ }^{2} / d_{l}{ }^{2}
$$

ここに， $d_{l}^{2}$ は勾配ベクトル $d_{n}$ の二乗和である. したがっ

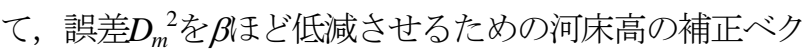
トル $\delta \Sigma_{n}$ の最適解は式(11)で表わされる.

$$
\delta z_{n}=-\beta D_{m}{ }^{2} \cdot d_{n} / d_{l}{ }^{2}
$$

前述のように水面下河床点全てについて最適值を計算 することは困難である. そこで, 水面下河床高 $z_{n}$ の代わ りに，水面下メッシュにおけるいくつかの点の水深補正 係数 $\alpha_{n}$ の最適化を考えることにし，勾配べクトル $d_{n}$ を式 (12)で与える.

$$
d_{n}=\left(\delta D_{m}{ }^{2}\right)_{n} / \delta \alpha_{n}
$$

河床高の場合と同様の手順で誤差 $D_{m}{ }^{2}$ を $\beta$ ぼ低減させる ための水深補正係数の補正ベクトル $\delta \alpha_{n}$ は式(13)で表わ される.

$$
\delta \alpha_{n}=-\beta D_{m}{ }^{2} \cdot d_{n} / d_{l}{ }^{2}
$$

式(12)の勾配ベクトル $d_{n}$ を求め, 式(13)によって各点の水 深補正係数 $\alpha_{n}$ を繰り返し補正することによって, 河床高 の最適值が求まる.

\section{(3) 計算方法と計算結果}

式(12)の勾配ベクトル $d_{n}$ は感度分析によって求める. 前述のように, 全ての計算格子点において感度分析を行 い，河床形状を計算することは実用的でないため，感度 分析においては，水面下となるいくつかの格子点におい て勾配ベクトルを求め，全格子点に内挿寸る. また，水 深補正係数 $\alpha$ （とそれに応じた河床高）の微小変化量 $\delta \alpha_{n}$ は対象とする格子点を中心とした一定距離スケールの円 錐状に与える. このとき, 水位比較点が非水没となる場 合があるため, 非水没部分の仮の水位 $H$ 水域の水位を 境界条件として，ラプラス方程式によって求めることに 


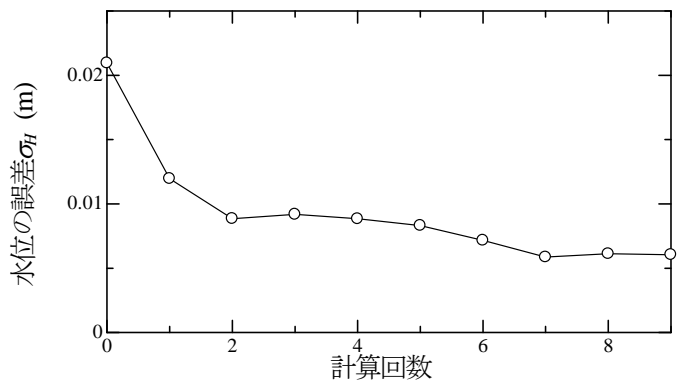

図-12 最適化手法による水位の誤差 $\sigma_{\mathrm{z}}$ の変化

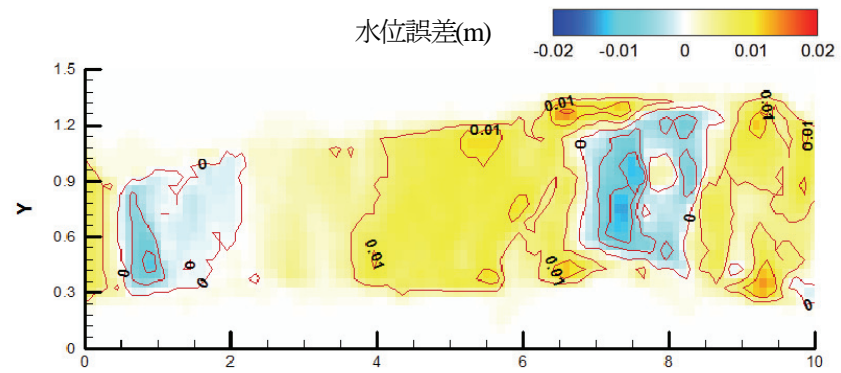

（a）水位の誤差分布

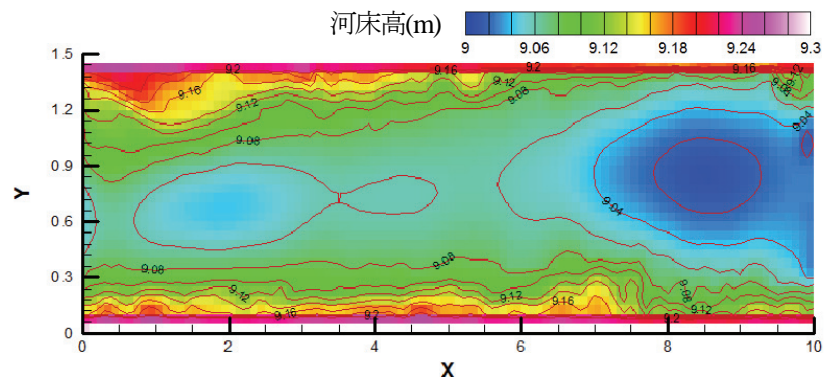

(b) 河床形状

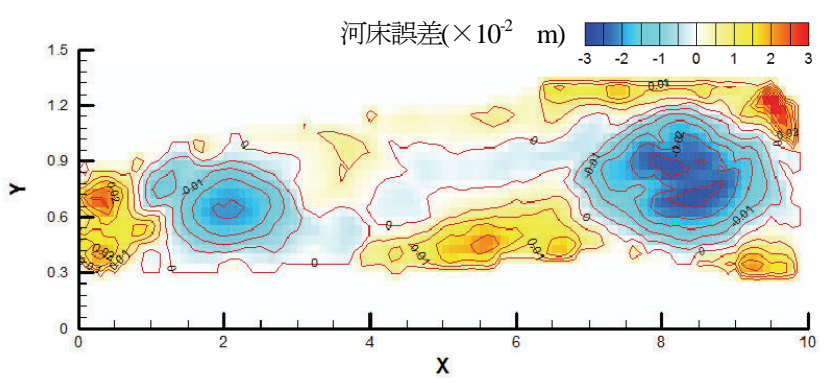

(c) 河床の誤差分布

図-13 最適解における水位と河床高の誤差分布

する.

図-8に示したように，河床高が真值よりも低い場合は 水位に対する感度が小さくなり，最適值を求めることが 困難となることから， $\alpha$ の初期值は0を与える. したがっ て，本推定手法では水深をゼロとするような河床高から 修正量を最小としながら最適值を求めるため, 水深が最 も小さい局所最適值を求めることになる.

図-11に水面下河床高の力学的内挿補間法の流れを示 す. 本手法は計算条件の設定，与えられた河床形状に対 する誤差の計算（河床形状の評価）及び水深補正係数 $\alpha$ を微少量変化させる計算（感度分析）に分けられる．本 来計算条件の設定において，下流端水位と水位比較点の 水位はレーザ計測から求めるものであるが，ここでは手 法の妥当性を検討するため, 真值の河床高を与えた計算 結果を用いている。.また，水域の全点を水位比較点とし
ている. 本推定手法においては，その仮定（式(7),(8)の 導出）から, 誤差 $D_{m}{ }^{2}$ の低減割合 $\beta$ を十分小さくする必要 がある.ここでは，直前に計算された，計算 1 ステップ 辺りの誤差 $D_{m}^{2}$ の低減割合を与える. 計算は $\beta$ 多 $\varepsilon=10^{-3}$ 以 下となるまで続ける.

図-12に水位誤差の変化, 図-13に最適解における水位 の誤差分布，河床形状とその誤差分布を示す．水位誤差 を見ると，誤差は一定值以上に小さくならないが，誤差 は一様に低減されている. 得られた河床形状を見ると, 局所的に誤差を含むが，図-2(a)の河床形状の真值の特 徵を捉えており，実用的な精度で河床高データが得られ ると考えられる. 本論文では，流量と粗度係数の真值を 与えているなど，実河川への実用化には課題が残されて いるものの，河川レーザ計測の大きな課題である水面下 の河床高について，力学的条件を満たすように得られる ことを示したことには意義がある.

\section{4. 結論}

本研究では，河川レーザ計測の大きな課題の一つであ る水面下河床高データの久損について，レーザ計測によ り得られる水面形に着目し，運動方程式を介した水面下 河床高の力学的内挿法を定式化した．本手法を実験水路 に適用し，安定的に収束解が得られることを示した。河 床形状の計算結果は, 計測值の特徵を捉え, 本手法によ り実用的な精度の河床高データが自動的に得られること を示した.

謝辞：本研究は，平成19年度科学研究費補助金基盤研究 (C)（課題番号 : 19560513，代表 : 河原能久），同若手 研究(B)（課題番号：19760341, 代表 : 内田龍彦）, 及 び財団法人中国電力技術研究財団（代表 : 内田龍彦）の 支援によって行われた. ここに記して謝意を表する.

\section{参考文献}

1) 航空レーザ測量ハンドブック，(財)日本測量調査技術協会, 2004.

2) 国土交通省国土地理院: 航空レーザ測量による数值標高モデル (DEM) 作成マニュアル (案)，2006.

3) 川本一善, 舘健一郎, 武富一秀, 金木誠 : レーザースキャナデー タを用いた中小河川河道モデルの作成手法に関寸る研究，河川技 術論文集, 第8巻, pp.533-538, 2002.

4) 傳田正利, 時岡利和，天野邦彦：レーザプロファイラ及び空中写 真を用いた河川中流域の河床高推定手法の開発，河川技術論文集， 第12巻, pp.145-150, 2006.

5) 内田龍彦, 河原能久, 山水綾, 渡刃豊, 森山学: ヘリコプタに搭 載した高精度3Dレーザスキャナによる河川の物理環境の計測，河 川技術論文集，第13巻，pp.243-248，2007.

6) 福岡捷二 : 洪水流の水面形観測の意義と水面形の基づく河川の維 持管理技術，河川技術論文集，第12巻，pp.1-6，2006.

7) 内田龍彦, 河原能久 : 二次元浅水流の保存型CIP陽解法の開発と その検証，応用力学論文集，Vol.9，pp.917-924，2006.9

8) 村松正和著 : 最啇化法，共立出版株式会社，2002.

(2007. 9. 30受付) 